almost exactly twelve months previously. Two of these fish were recaptured on the same stretch of gravel as that on which they had been captured the previous year; both were half-spent females. All identifications are supported by scale examinations. No instance occurred of the recapture of a sea trout, tagged in 1953, in a different spawning burn the following year.

These observations suggest that sea trout return to their native stream and that they spawn at approximately the same time of year each year.

Brown Trout Research Laboratory, W. M. SHearer

Faskally House, Pitlochry. March 15.

1 Lamond, H., "The Sea Trout. A Study in Natural History"' (Sherratt and Hughes, Manchester, 1916).

- Nall, G. H., Fisheries, Scotland, Salmon Fish., 1929, 4 (1929).

\section{Transformation of the Lewis Groups of Human Red Cells}

Is general, the blood-group antigens appear to form a permanent part of the human red cell in vivo; they persist throughout the life of the cell not only under normal conditions, but also after transfusion into the circulation of a recipient with a different set of antigens. Moreover, antigens characteristic of the recipient do not appear upon the transfused cells. These statements have been shown to be true for the $A B O, M N S, R h$, Lutheran, Kell, Duffy and Kidd antigens; but the Lewis antigens have not previously been investigated in this respect.

The Lewis system was discovered by Mourant ${ }^{1}$ in 1946 : the red cell antigen $L e^{a}$ is the only bloodgroup antigen yet known which is inherited as a Mendelian recessive character ${ }^{2}$. The antigen $L e^{b}$ has so far defied precise genetic analysis, and the gene controlling it may not be allelic to that for $L e^{a}$. The antigens may be detected on the red cell and in the serum and secretions. There are three red-cell phenotypes occurring naturally in adult blood as shown in Table 1.

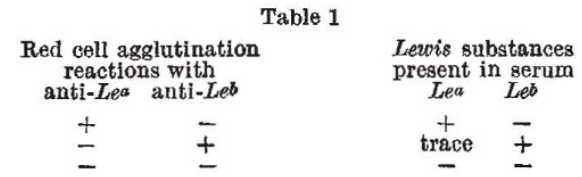

Grubb and Morgan ${ }^{3}$ first showed that the Lewis substances are present in secretions and serum, and Grubb $^{4}$ suggested that the Lewis antigens are primarily tissue antigens. A blood-group antigen showing somewhat similar behaviour is found in cattle - this is the $J$ system : the $J$ substance is present on the red cells and also in the serum. Stormont, ${ }^{5}$ has shown that $J$-negative cells acquire $J$ substance from the plasma in vivo and in vitro. It is known that the $L e^{a}$ reactivity of the red cell diminishes after repeated washing ${ }^{3}$, and Brendemoen ${ }^{6}$ showed that the washings inhibited anti-Le $e^{a}$ serum.

It was thus of interest to see whether the Lewis red cell antigens were changed in vivo after transfusion into a patient of different Lewis group. A transfusion from an $L e(a+b-)$ donor was given to a patient of group $L e(a-b+)$. When the two kinds of blood in a post-transfusion sample from the patient were separated (by differential $R h$ agglutina- tion) the donor's cells were found to have become $\operatorname{Le}(a+b+)$.

The transformation can be reproduced in vitro. The results of mixing group $A_{2}$ red cells and plasma of different Lewis phenotypes are shown in Table 2. 1 volume of packed red cells to 10 volumes of heparinized plasma (containing streptomycin and terramycin) were continuously shaken at $35^{\circ} \mathrm{C}$. The plasma was renewed every $24 \mathrm{hr}$.

Table 2 shows that $L e(a+b-)$ cells, after $24 \mathrm{hr}$. in $L e(a-b+)$ plasma, have become Le $(a+b+)$; $L e(a-b+)$ cells in $L e(a+b-)$ plasma have also become $L e(a+b+)$. (The results were the same when $O$ cells and plasma were used.) It was further observed that after three days $L e(a+b-)$ and $L e(a-b+)$ cells lose their antigens to $L e(a-b-)$ plasma, while the $L e(a-b-)$ cells can acquire either antigen.

Table 2. REActions of RED BLOOD CELLS WITH Lewis ANTISERA AYTER INOUBATION IN PIASMA FROM DIFFERENT DONORS FOR $24 \mathrm{HR}$.

\begin{tabular}{|c|c|c|c|c|c|c|}
\hline \multirow{2}{*}{$\begin{array}{l}\text { Plasma from } \\
\text { persons of } \\
\text { Levois pheno- } \\
\text { type }\end{array}$} & \multirow[t]{2}{*}{$\begin{array}{l}\text { Lewis sub- } \\
\text { stances in } \\
\text { the plasma } \\
\text { Lea Leb }\end{array}$} & \multicolumn{5}{|c|}{$\begin{array}{c}\text { Red cells of Lewis group } \\
L e(a+b-) \text { Le }(a-b+) \text { Le(a-b-) } \\
\text { reactions with anti- }\end{array}$} \\
\hline & & $L e^{a} L e^{b}$ & Lea & Leb & Lea & Leb \\
\hline $\begin{array}{l}\operatorname{Le}(a+b-) \\
\operatorname{Le}(a-b+) \\
\operatorname{Le}(a-b-)\end{array}$ & $\underset{-}{\operatorname{trace}} \pm$ & $\begin{array}{l}+ \\
+ \\
+\end{array}$ & \pm & $\stackrel{+}{+}+$ & $\stackrel{+}{-}$ & $\underline{+}$ \\
\hline
\end{tabular}

- After three days, these reactions were extremely weak, whereas the other agglutination reactions were almost as strong as those given by fresh cells.

These findings may be correlated with the aberrant Lewis reactions given by the red cells of infants ${ }^{2}$ and pregnant women ${ }^{7}$ (where perhaps the normal level of Lewis substances in the plasma is disturbed). The absence of the $L e(a+b+)$ phenotype in adults may be accounted for by the low level of $L e^{a}$ substance in the serum of $L e(a-b+)$ people.

It seems possible that red cells simply adsorb the Lewis antigens in vivo and that the fundamental expression of the system is to be found in the serum antigens.

We wish to thank Dr. W. M. Davidson, of King's College Hospital, for sending blood from patients who had been transfused.

Medical Research Council

Blood Group Research Unit, Lister Institute, London, S.W.1.

Joan S. SNFath

\section{P. H. A. SNeAth}

National Institute for Medical Research, London, N.W.7. March 18.

1 Mourant, A. E., Nature, 158, 237 (1946).

- Andresen, P. H., Acta Path. Microbiol. Scand., 24, 616 (1947). ' Grubb, R., and Morgan, W. T. J., Brit. J. Exp. Path., 80, 198 (1948). ' Grubb, R., Rev. d'Hem., 5, 268 (1950).

stormont, C., Proc. U.S. Nat. Acad. Sci., 35, 232 (1949).

- Brendemoen, O. J., J. Lab. Clin. Med., 84, 538 (1949).

"Brendemoen, O. J., Acta Path. Microbiol. Scand., 31. 579 (1952).

\section{Colour Anomaly, the Rayleigh Equation and Selective Adaptation}

So long ago as 1878, von $\mathrm{Kries}^{1}$ reported that adapting lights fail to upset colour matches. This observation was modified in 1934 by Prof. W. D. Wright, who showed that lights of very high intensity, above about 15,000 photons, do upset colour matches'. Wright considers the breakdown at glare intensities to be due to radical photochemical ehanges. G. S. 